Article

\title{
Using Cartographic Documents to Provide Geoinformation on the Rights to Real Estate-Taking Poland as an Example
}

\author{
Marek Ogryzek ${ }^{1, *(D)}$, Anna Klimach ${ }^{1}$ (D), Dominik Niekurzak ${ }^{1}$ and Michał Pietkiewicz ${ }^{2}$ (D) \\ 1 Faculty of Geodesy, Geospatial and Civil Engineering, Institute of Geography and Land Management, \\ University of Warmia and Mazury in Olsztyn, 15 Prawochenskiego Street, 10-720 Olsztyn, Poland; \\ anna.klimach@uwm.edu.pl (A.K.); dominik.niekurzak@student.uwm.edu.pl (D.N.) \\ 2 Faculty of Law and Administration, Department of International Public Law, University of Warmia and \\ Mazury in Olsztyn, 98 Warszawska Street, 10-719 Olsztyn, Poland; michal.pietkiewicz@uwm.edu.pl \\ * Correspondence: marek.ogryzek@uwm.edu.pl
}

Received: 16 October 2019; Accepted: 25 November 2019; Published: 26 November 2019

\begin{abstract}
The current and planned EU regulations concerning INSPIRE have forced the Member States to develop national geoportals. The aim of creating geospatial data infrastructure was to unify the exchange of data at a national level, and consequently to create the INSPIRE geoportal by the Community Research Centre of the European Commission (JRC), which is to be the center of the European network of geospatial data infrastructure. New opportunities and new solutions to the problems have emerged through the use of thematic layers. The rights to the land each have potential restrictions on its use, and these rights can sometimes prevent the land from being used for its intended purpose. The purpose of the article is to demonstrate the possibility of developing maps showing the utility networks and the right to the land acquired by the utility company. The authors carried out a SWOT analysis of the systemic use of cartographic documents as a way of disclosing the rights to real estate in order to set up utility networks in Poland. The authors examined the impact of this solution on future property owners (investors) to provide them with full knowledge about a given area of real estate. Remote sensing methods may be useful for the disclosure of rights on maps of technical infrastructure, because currently there is no such information in the systems. The developed solution should be used by both local and national geoportals.
\end{abstract}

Keywords: utility networks; cartographic documents; property restrictions; GIS

\section{Introduction}

In 2016, the United Nations (UN) adopted 17 Sustainable Development Goals. Sustainable development is a way of meeting the needs of the present without compromising future generations. Sustainable development can be obtained by harmonizing the following elements: economic growth, social inclusion, and environmental protection. Two of these goals are: Zero Hunger, and Clean Water and Sanitation. Implementing these goals requires land, along with information about what the land can be used for. Such data are essential for sustainable farming, which will then lead to increased food production and the prevention of hunger [1]. Providing these goals is possible through the implementation of the specific targets indicated by the UN. One specific target is to ensure a sustainable food production system, which will be possible by selecting areas where no line investments such as pipelines or cables are planned to be carried out and so cultivation will not be threatened by the construction of utility transmission equipment.

The role of transmission companies is providing off-takers with access to electricity, water, or other utilities. The research was carried out in relation to Polish legal provisions. The applied solution can be 
used, after making appropriate modifications, with respect to other countries. Providing those utilities often requires distributing them over considerable distances. Companies also deliver utilities to large plants and enterprises and are delivered using utility networks that connect the transmission company with the off-taker. The equipment used may be different, depending on what they deliver. The utility company should have the right to those devices and the right to install them on an area of real estate. The equipment can be installed on the real estate without the consent of the owner of the land, or even against their will. The transmission company can obtain various rights to set up utility networks on a piece of land, placing limits on ownership rights. These restrictions can take various forms; for example, it may be that the device is located on the property, or that cables run above the property. In Poland, the utility companies usually operate as commercial law companies, with or without the participation of the State Treasury. The supply of utilities is regulated by specific provisions depending on the given utility. Therefore, it is necessary to define the rights to real estate as a whole, rather than for individual plots of land, as one area of real estate may consist of several plots, each with different restrictions. In addition, the presence of transmission devices on an area of real estate affects a wide range of people, so it is necessary to bring about a legally regulated situation to ensure that the devices as well as the relevant rights and restrictions are disclosed for each of the plots comprising an area of real estate.

In order to create cartographic documents showing the rights to real estate for the foundation of devices on real estate would require a database to be created. The authors suggest that the developed thematic layer should be in the shape format. Such a solution will enable searches of the database using SQL language and with visualization in open source, commercial, and WEB GIS software. Additionally, it will enable integration with cadastral databases such as the 3D database for the Land Administration Domain Model (LADM) [2]. It is consistent with the conceptual model IndoorGML and the LADM [3], which introduced an approach to determining the availability of internal spaces based on access rights. Once all the information is stored in the database, a wide range of queries can be performed and the results can be visualized in various front-end visualization software (FME, 3DQGIS, RHINO, ArcGIS) capable of reading ST_Geometry data types [4] and data (binary or text column) TINYBLOB, TINYTEXT, BLOB, TEXT, MEDIUMBLOB, MEDIUMTEXT, LONGBLOB, and LONGTEXT types. The possibility of supplementing the LADM, which is the reference model for land information systems, would bring many benefits and opportunities, not just the ability to build a 3D cadaster in Poland. The new functionalities include better structuring of the rights, responsibilities, and restrictions (and related source documents); better fitting in the information infrastructure, both national (e.g., valuation, taxation, buildings, address, and registration of people) and international (e.g., INSPIRE cadastral parcels); and future capabilities for representing three-dimensional spatial units (e.g., legal spaces related to apartments or utility infrastructure) [5]. The most attractive solution was the Pan-European Spatial Data Infrastructure (SDI), which used existing national and regional data infrastructures. This was resolved at the political level by establishing a European framework directive on infrastructure for spatial information in the European Community - INSPIRE [6]. For SDI, the technical framework must be accompanied by a set of organizational rules and agreements. The technical framework has been strengthened under European law thanks to INSPIRE. Changes in the display of rights on maps can occur through coordination at the national level using European law. Member States shall ensure that metadata are created for spatial datasets and services $[7,8]$. These collections correspond to at least one INSPIRE topic. This metadata must be updated according to the data and services based on EN ISO 19115 and EN ISO 19119 [9].

Definitions of real estate can be found in various pieces of legislation. In the Polish Civil Code [10], the following types of real estate are listed: plots, premises, and buildings. Real estate is a rare and unique asset. The definition of real estate is presented in the Civil Code [10]. According to the Civil Code, real estate is defined as the parts of the ground surface constituting a separate object of ownership (land) as well as the buildings permanently connected with the land, or parts of such buildings if, pursuant to special provisions, they constitute a separate real estate. According to the Real Estate 
Management Act [11], real estate is described as land and the components thereof excluding buildings and premises constituting a separate subject of ownership. According to Rudnicki [12], there are two definitions that do not allow this concept to be understood differently. Two types of boundaries of real estate can be distinguished and defined: spatial boundaries and legal boundaries. The legal boundaries of an area of real estate are determined "artificially". The property may consist of several plots of land that do not necessarily have to be adjacent. It does not change the fact that they legally constitute one property.

As indicated in Figure 1, registration plots marked in orange may constitute a single piece of real estate, provided that they are owned by the same owner and kept in the same land and mortgage register. Under Polish law, each area of real estate is kept in its own land and mortgage register. The Supreme Court ruling of 26 February 2003 [13] states that one land and mortgage register can be assumed for two adjacent plots belonging to one owner. Within the meaning of the Civil Code [10], these plots constitute one area of real estate. The Act on Land and Mortgage Registers [14] establishes that, at the request of the owner, separate plots of land belonging to them can be combined into in one land and mortgage register, provided that they constitute a part of a single enterprise, even if they are not adjacent. However, determining the boundaries of spatial rights is difficult due to the need to determine the borders to which the owner of the property may use his right. An attempt to indicate these limits can be found in the Civil Code, which states that the upper and lower limits depend on the socio-economic purpose of the property [15].

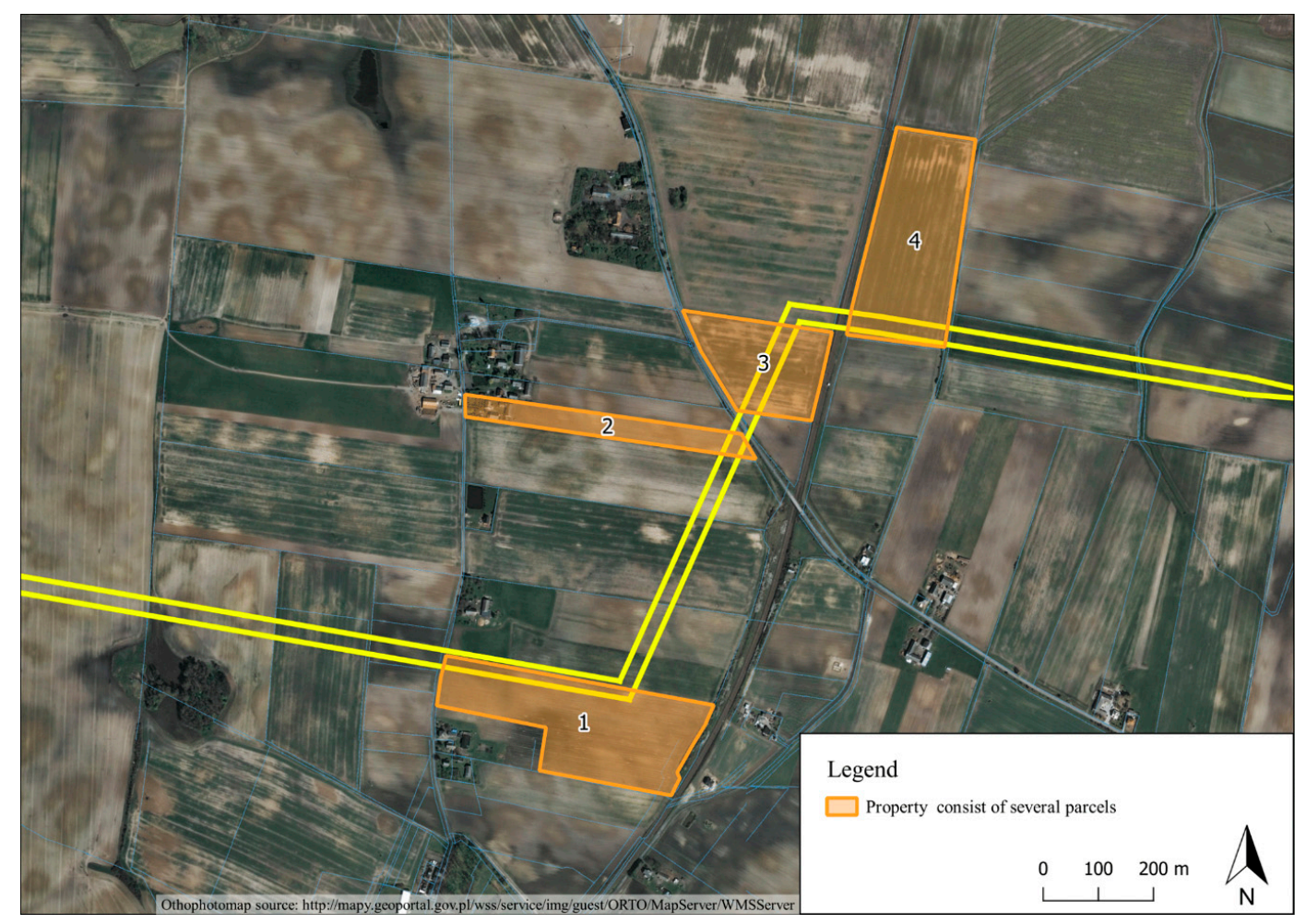

Figure 1. The property consists of several parcels. Source: Own study based on [16].

Rights to the goods of others are as old as the right to property and the oldest right is easement. There were already provisions in Roman law dividing them into rights to urban and rural land [17].

Land is not "flat", it is a three-dimensional space [18]. This is significant when installing utility devices on real estate. Such devices may be located below, on, and above the ground. Determining the "horizontal" boundaries of an area of real estate is possible, thanks to natural or artificial boundaries. The Geodetic and cartographic law [19] provides that the land and building register contains information on borders, among other things. Therefore, it should not be a problem defining the boundaries of real 
estate because, in accordance with the geodetic and cartographic laws [20], access to this information is possible after demonstrating a legal interest. The situation is different for the 'vertical' borders of real estate. In the Civil Code [15], a norm is included from which it follows that the "vertical" boundaries of real estate can be determined using the socio-economic purpose clause. Therefore, the limits of exercising the right of ownership to an area of real estate are given. However, the application of this clause does not resolve the problem of whether the facilities for which a utility easement can be established are within these limits or not. Therefore, it is necessary to constantly evaluate the cadastral system in Poland, therefore, the next stage should be the access and ability to manage spatial information [21].

These vertical boundaries have to be set separately for each property. When determining the boundaries, it is necessary to check the purpose of the real estate in the local zoning plan. This includes, among other things, determining the purpose of the area and determining the development and development conditions of the area [22].

The right to an area of real estate does not extend to every element within the real estate (Figure 2). The principle of superficies solo cedit does not apply to everything that is on the property. This rule does not apply to flowing surface water, groundwater, and most mines [23,24]. Even if they are on the property, they are not owned by the landowner. Utility networks may be the property of the real estate owner, but it is most often the property of the utility company (i.e. the principle of superficies solo cedit does not apply to them).

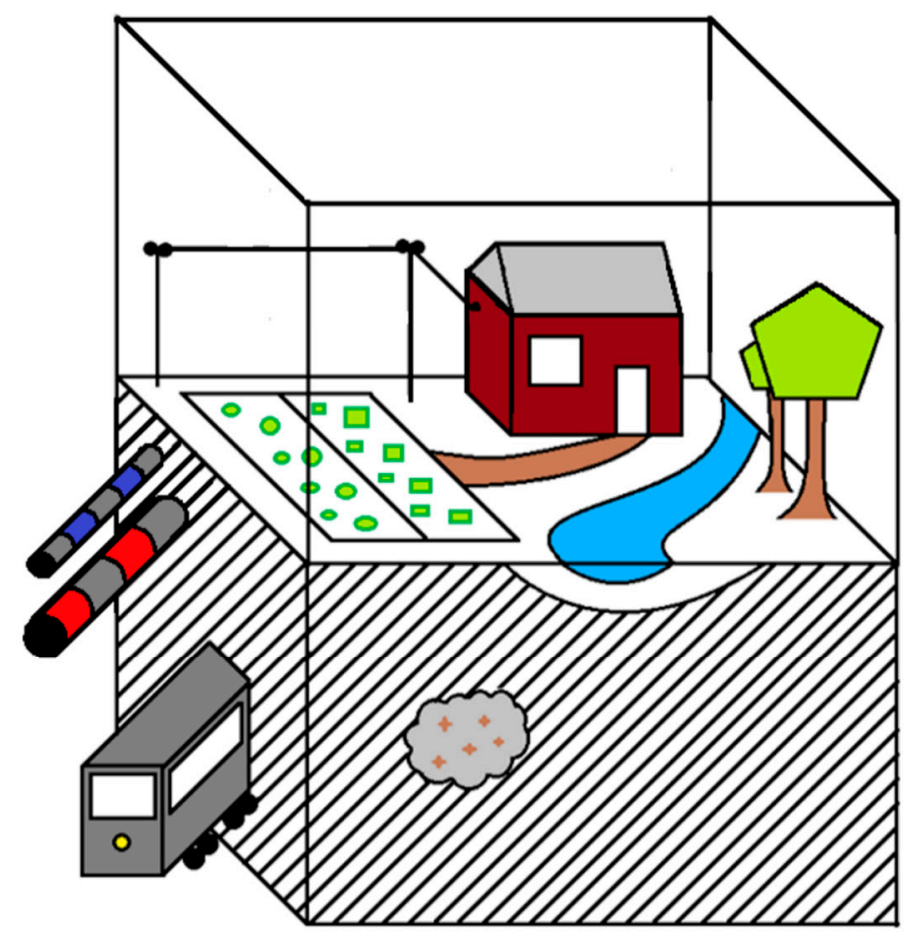

Figure 2. Schematic representation of the property boundaries and elements that may be situated on the property. Source: Own study.

The presence of utility networks on an area of real estate can significantly restrict the owner of the property. Therefore, the owner should know the course of the utility networks, the entity that has the rights to them as well as the type of right involved.

On agricultural land, all of the following restrictions on property rights may apply. Land used for agricultural purposes is of particular value because it is used for the production of food, which is essential for the life of the population. According to the United Nations, agriculture is the largest employer in the world, providing livelihoods for $40 \%$ of today's global population (SDG Zero Hunger) [1]. The United Nations also points out that around 840 million people do not have access to 
electricity worldwide; most of these people live in rural areas. Rural development needs to be nurtured through full factual and legal information about the ownership of real estate. The holder of the land will be able to find out where utility networks are located, and where the law imposes restrictions by looking for property rights restrictions.

Remote sensing techniques make it possible to replace time-consuming manual digitization by more reliable automatic mapping procedures, thereby providing useful information on agricultural activity to update regional databases [25]. The disclosure of rights and restrictions on land, especially in the context of its protection in connection with new technologies and remote sensing, will enable the quick verification of the application of the law by farmers, investors, and local government units. An example of such a solution is EU directive 2007/60/CE. The Setting Plan (PAI-Piano di Assetto Idrogeologico) was introduced to identify areas exposed to serious hydrogeological risks. Their disclosure on maps of land use regulations and restrictions, and the implementation of mapping rural areas with widespread plastic covered vineyards using true color aerial data will make it possible to verify the application of the rights introduced by imposing both of these thematic layers in GIS technology [26].

The main goal of the research was to show that cartographic studies can present not only the technical situation of real estate, but also the legal situation. The use of such studies was tested on utility devices, because transmission entrepreneurs should have information about their rights to these devices.

\section{Materials and Methods}

The research was carried out in several stages. First, the authors identified the problem. Then, the authors characterized the concept of real estate and pointed out the problems that arise when treating real estate as a three-dimensional space in which utility networks are located. Then, they established the basis of the rights on which the utility companies could acquire the right to real estate in order to set up utility networks. The next stage of the research was to present the authors' concept for the creation of cartographic documents showing the disclosed rights to real estate in terms of installing devices on an area of real estate. It is a concept that can be used by utility companies to run industry portals, and by national units for the whole country. Apart from utility companies, interested parties including anyone wishing to purchase real estate may wish to take advantage of such studies. Thanks to this, they will know what rights are established on the real estate. A property appraiser may also be interested in obtaining information about the rights to real estate, which will be needed when looking for real estate for comparisons in the valuation process. Often, these entities are unaware that a utility network runs through their property, and what rights the owner of the device holds for the real estate in question. As the last element of the study, the authors, supported by one of the utility companies, carried out a SWOT (Strengths, Weaknesses, Opportunities and Threats) analysis that was aimed at demonstrating whether the proposed solution would be helpful to utility companies.

Figure 3 shows the test procedure.

While carrying out the research, we used the formal-dogmatic method to analyze the legal provisions. Orthophotomaps from Geoportal were used as background maps, with new thematic layers being developed in QGIS v3.4 software. Due to the fact that the INSPIRE Directive has led to a certain unification of geoportals, we assumed that their solution could also be used in other countries [27]. Through the introduction of this directive, public registers have been harmonized so that data from various registers can be obtained and shown. The main purpose of creating geoportals in an EU Member State was to facilitate decision-making and business development by creating a European research center of the INSPIRE geoportal commission, which is to be the Center for the European Spatial Information Infrastructure. Complementing the Polish geoportal, followed by other national geoportals in the future, with the proposed thematic layer disclosing rights will enable the implementation of the above purpose. 


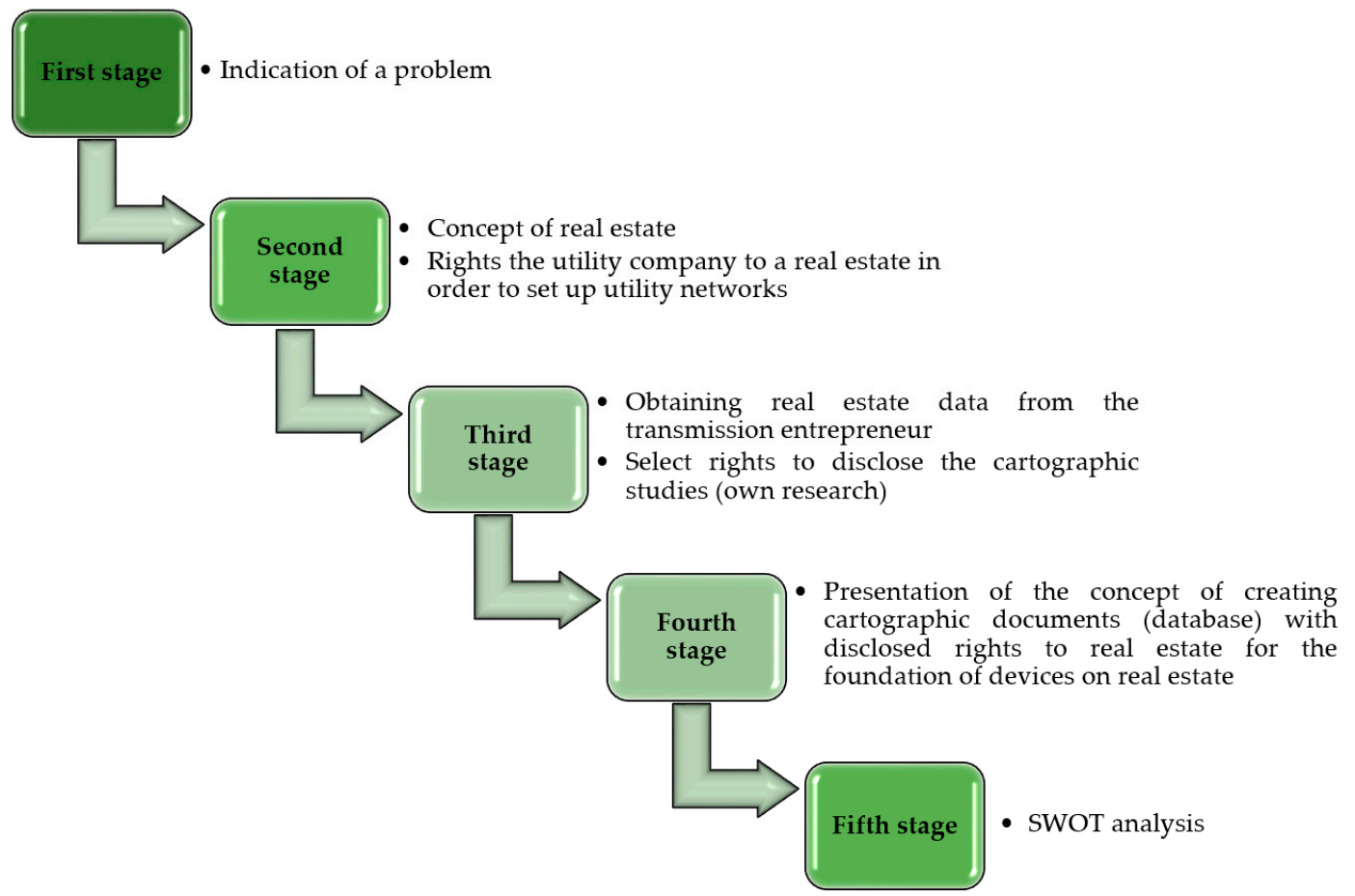

Figure 3. Procedure of conducted research. Source: Own study.

The SWOT analysis was developed on the basis of an interview with a utility company.

The paper used the concept of utility networks in relation to devices used to supply or remove liquids, steam, gas, electricity, and others. Due to the fact that the article addresses issues related to the deprivation of these devices on real estate, only the situation of devices owned by utility companies has been discussed. There is no legal definition of a utility company in Polish law. A utility company is an entity that prepares investments consisting in the construction of a utility network, and which participates in determining the location of utility networks. A utility company may be a private entity or a public entity.

Through the concept of "cartographic documents", the authors understand maps for design purposes, basic maps, and map portals used by utility companies in carrying out their activities as well as other entities that want to obtain information about the rights on the basis of which a utility network was founded.

The background map was downloaded from geoportal [16]. The course of planned utility facilities was made available by the utility company as well as cadastral data. For the implementation of the study, the authors presented all the possible rights in order to check the assumptions of the study.

\section{Results and Discussion}

\subsection{Rights to Place Devices on the Property}

The Civil Code [28] uses the term "devices used for supplying or removing liquids, steam, gas, electricity and others". The doctrine and the relevant case law use the term "utility networks" [29]. Article 49 of the Civil Code is an exception to the principle of superficies solo cedit. Transmission equipment does not form part of the real estate on which it is located, if it is part of an enterprise [30].

An entity that wants to set up utility networks on the ground should have the right to construct these devices. If this does not happen, a situation of the non-contractual use of land arises. Using the property without any legal basis infringes the rights of the owner of the property, or other entities holding the right to it. An entity that wants to build a network in a given place can do so on the basis 
of various legal titles. The foundation of the devices will be associated with various encumbrances on the property [31].

The use of real estate to build utility networks may take place on the basis of various rights. Table 1 presents the grounds for acquiring the right to land that may be applicable when acquiring land on which to construct utility networks. The right of ownership is naturally the right with the broadest scope, followed by the right of perpetual usufruct to real estate, which is a right peculiar to Poland, being between ownership and a long term lease, while the narrowest scope of rights to land are those of the limited property rights [32].

Table 1. Analysis of selected rights that can be used to set up utility networks on real estate.

\begin{tabular}{|c|c|c|c|c|}
\hline Right & Permissions/Responsibilities & The Legal Boundaries & Negotiability & $\begin{array}{c}\text { The possibility of } \\
\text { Obtaining a Building } \\
\text { Permit }\end{array}$ \\
\hline Ownership & $\begin{array}{ll}- & \text { Use } \\
- & \text { Deriving benefits } \\
- & \text { Maintenance }\end{array}$ & $\begin{array}{ll}- & \text { Act } \\
- & \text { Rules of social coexistence } \\
- & \text { Socio-economic purpose of } \\
\text { the law }\end{array}$ & + & + \\
\hline Perpetual usufruct & $\begin{array}{ll}\text { - } & \text { Land association excluding } \\
\text { other people. } \\
\text { - } \quad \text { Maintenance of one's own right }\end{array}$ & $\begin{array}{ll}- & \text { Act } \\
- & \text { Rules of social coexistence } \\
- & \text { Socio-economic purpose of } \\
\text { the law } \\
\text { - }\end{array}$ & + & + \\
\hline Usufruct & Using and deriving benefits & $\begin{array}{l}\text { - The scope of use can be } \\
\text { limited by excluding } \\
\text { specified benefits. } \\
\text { The use of the property can } \\
\text { be limited to a } \\
\text { designated part. }\end{array}$ & - & + \\
\hline Ground easement & $\begin{array}{l}\text { The owner of the dominant } \\
\text { property may use the encumbered } \\
\text { real estate in the designated scope, } \\
\text { The owner of the encumbered } \\
\text { property is restricted from carrying } \\
\text { out specific activities thereon, } \\
\text { The owner of the encumbered } \\
\text { property may not exercise } \\
\text { certain rights }\end{array}$ & $\begin{array}{ll}- & \text { Act } \\
- & \text { Contract } \\
- & \text { Rules of social coexistence, } \\
& \text { taking into account } \\
\text { local customs }\end{array}$ & - & + \\
\hline Utility easement & $\begin{array}{l}\text { - The owner of the encumbered } \\
\text { property is restricted from carrying } \\
\text { out specific activities thereon, } \\
\text { The owner of the encumbered } \\
\text { property may not exercise } \\
\text { certain rights } \\
\text { The utility company may use the } \\
\text { encumbered property in the } \\
\text { designated scope in accordance } \\
\text { with the purpose of these devices } \\
\text { (utility easement). }\end{array}$ & $\begin{array}{ll}- & \text { Act } \\
- & \text { Contract } \\
- & \text { Rules of social coexistence } \\
& \text { taking into account } \\
& \text { local customs }\end{array}$ & + & + \\
\hline $\begin{array}{l}\text { Contract with the } \\
\text { owner of the property } \\
\text { (e.g., lending } \\
\text { agreement, rent, } \\
\text { lease) }\end{array}$ & $\begin{array}{l}\text { - The lender undertakes to allow the } \\
\text { recipient to use the goods given to } \\
\text { him for free } \\
\text { - } \quad \text { Using objects } \\
\text { - } \quad \text { Using objects and deriving benefits }\end{array}$ & $\begin{array}{ll}\text { - } & \text { Act } \\
\text { - } & \text { Contract } \\
\text { - } & \text { Using objects in a way that } \\
& \text { is appropriate to its } \\
& \text { properties and purpose }\end{array}$ & + & $+/-$ \\
\hline $\begin{array}{l}\text { Administrative } \\
\text { decision }\end{array}$ & $\begin{array}{l}\text { They result from the content of } \\
\text { a decision. }\end{array}$ & $\begin{array}{l}\text { They result from the content } \\
\text { of the decision. }\end{array}$ & $+/-$ & + \\
\hline Special Act & $\begin{array}{l}\text { - They result from the content of } \\
\text { the act }\end{array}$ & $\begin{array}{l}\text { - They result from the content } \\
\text { of the act }\end{array}$ & + & + \\
\hline
\end{tabular}

Source: Own study based on legal acts.

The utility company can choose which property rights it wants to acquire, and how it wants to obtain then. Not all of the rights listed in Table 1 give the same entitlements to the utility company. In addition, not every right is transferable (i.e., in the event that the utility network is sold or merged with another utility company, the new entity will have to apply to re-establish the right). In some cases, these rights are sufficient for the company to obtain a building permit. The right to use the real estate is a necessary element, if the utility company applies for a building permit [33]. It would have to prove that it has the right to use the land, in accordance with the building law [34]. The right to 
enter an area of real estate and use it for construction purposes may result from property rights and from a contractual relationship. The right to enter and use the real estate for construction purposes must result from the content of that right or from the content of the contract. A ground easement does not grant the right to build encumbered real estate [35]. Obligation agreements such as rent and lease may result in the right to use an area of real estate for construction purposes. The content of the lease does not result from the building permission, so it must be specified in the content of the contract [36]. According to construction law, the management board also has the opportunity to build on land (this concerns permanent management within the meaning of the Real Estate Management Act [37]). Among the administrative decisions, it is worth pointing out the decision mentioned in Article 124 of the Real Estate Management Act [11], concerns the possibility of limiting the right to real estate in order to establish and carry out drainage lines, conduits, and devices for the transmission or distribution of liquids, steam, gases, and electricity as well as public communication and signaling devices, and other underground, on-ground, or above-ground facilities and equipment required to use these cables and devices. A temporary seizure of real estate or expropriation by restriction occurs on the basis of a decision issued by a starost-the head of the local authority-performing tasks in the field of government administration. The decision concerns the seizure of real estate in order to perform necessary activities on the property, or to provide access to perform these activities. Restricting the use of real estate by an authorized entity may occur ex officio or at the request of an entity interested in investing in an area of real estate. This procedure can only be used if it is intended to achieve a public purpose, and if this goal cannot be achieved other than by restricting the use of the property. In some cases, the legislator indicates which right a utility company may obtain. In the case of setting utility networks on land covered with flowing surface water, this is the right of an usufruct.

\subsection{Utility Networks and Related Rights on Cartographic Studies}

Utility networks are disclosed on industry portals of utility companies and surveying records of the utilities network (GESUT). The G-7 Technical Manual [38] indicates color markings and codes for various types of networks. Table 2 sets out the markings for gas lines.

Table 2. Cartographic designation for the gas network.

\begin{tabular}{|c|c|c|c|c|}
\hline Network Type & Color & First Letter of the Code & Network Type & Second Letter of Code \\
\hline \multirow{3}{*}{ Gas network } & \multirow{3}{*}{ Yellow } & \multirow{3}{*}{ G } & $\begin{array}{l}\text { High pressure } \\
\text { (Wysokoprężne) }\end{array}$ & W \\
\hline & & & $\begin{array}{l}\text { Semi-pressure } \\
\text { (Średnioprężne) }\end{array}$ & S \\
\hline & & & $\begin{array}{l}\text { Low-pressure } \\
\text { (Niskoprężne) }\end{array}$ & $\mathrm{N}$ \\
\hline
\end{tabular}

Source: Own study.

The gas network was determined on the map (Figure 4).

The literature indicates the possibility of using cartographic studies to reveal easements [39-43]. For example, maps can also indicate rights of way [44-46]. In addition to demonstrating rights in a given country, it is also possible to disclose rights under international law [47].

The use of real estate is associated with the possibility of locating devices on a plot of land [48], where the course and location of the devices is set out in map attachments, or occasionally in descriptive form [49]. The course of a designed line is shown in Figure 4. As already mentioned, the utility company must obtain the right to establish devices on a given area of real estate. The proposed cartographic solution presented in Figure 5 was to select a layer with the rights of the utility company to a specific plot (geodetic) of land, and the planned or existing line. Similar considerations can be found in the literature $[50,51]$. 


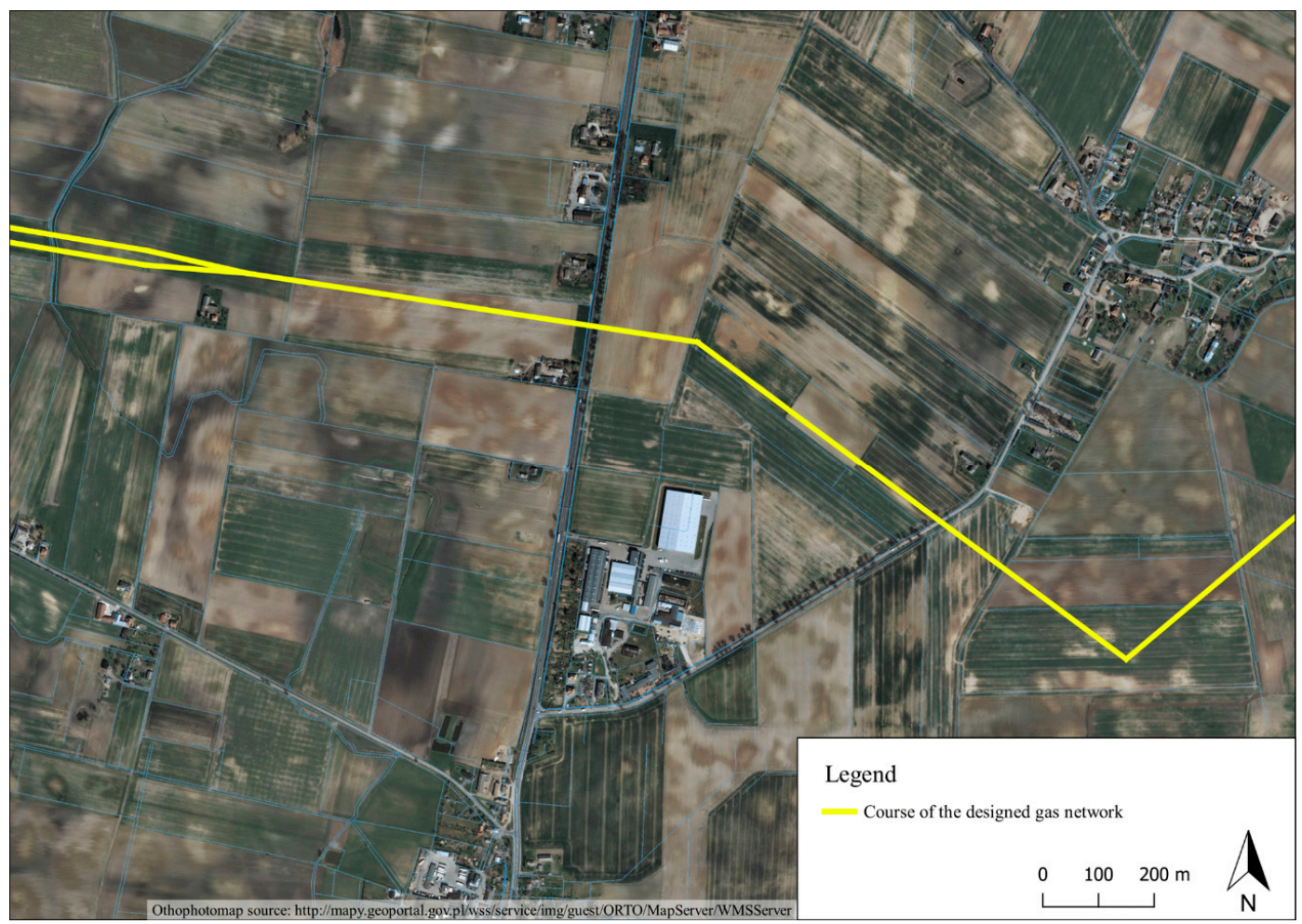

Figure 4. Marking of the gas network. Source: Own study based on [16].

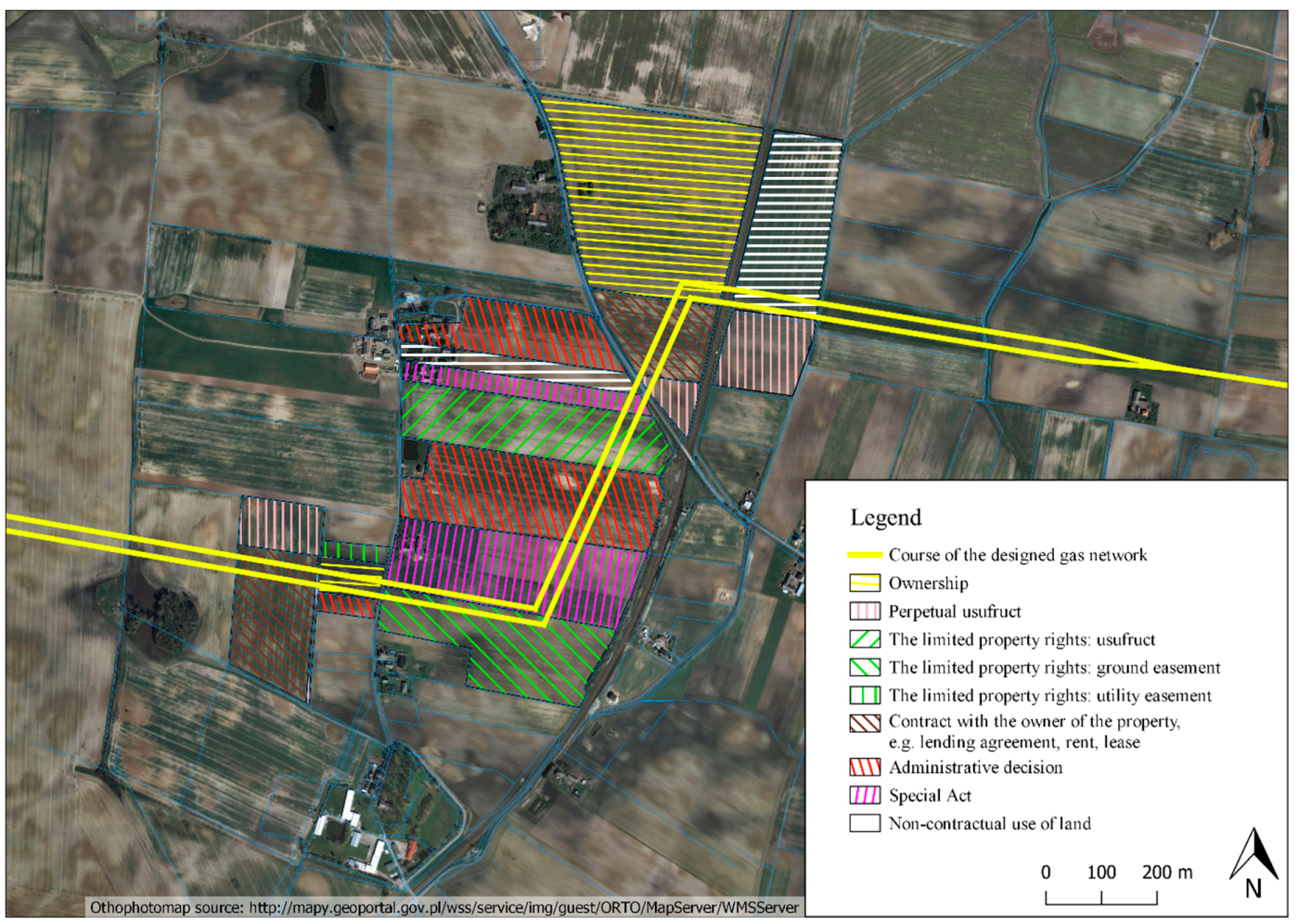

Figure 5. Thematic layer with the rights of the utility company. Source: Own study based on [16].

Based on Figure 5, we can conclude that for one investment, various different legal bases may be used to acquire the right to install equipment on the property. In the presented research, the authors propose a solution making it possible to identify: 
- $\quad$ where the utility networks are located;

- what utility networks are on the property;

- what rights are vested in the utility company to a given area of real estate.

Thanks to this combination, utility companies and property owners will be able to find all the pieces of information necessary to carry out various types of activities on the property in one place.

\subsection{SWOT Analysis}

The proposed solution, marking the legal basis on cartographic documents, is a solution that can have both strong and weak points. One of the strengths is that it is a useful solution for many entities. The disclosure of non-confidential information may also be useful for entities related to the real estate market services (e.g., property appraisers). Thanks to such studies, they will be able to gather more complete information about valued properties and those taken for comparison. One of the biggest threats and weaknesses is the lack of a statutory obligation to disclose all the rights to an area of real estate in public registers.

The presentation of utility networks and related rights on cartographic documents is important for both utility companies and owners/users of real estate. Based on the SWOT analysis (Figure 6), there are more opportunities and strengths than weaknesses and threats to such a solution.

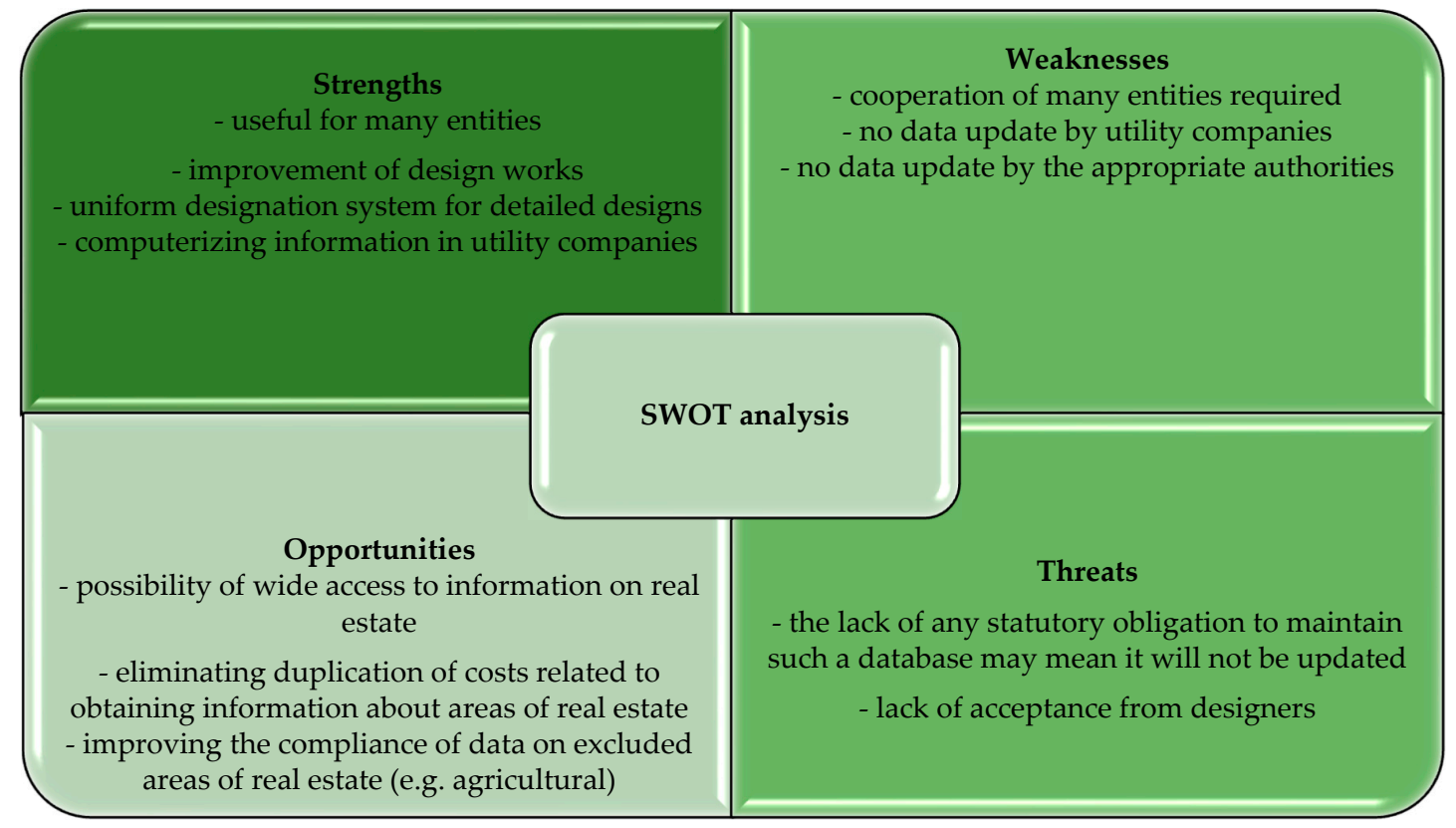

Figure 6. SWOT analysis of the use of cartographic documents to reveal rights to real estate. Source: Own study.

The most serious threat seems to be the lack of a statutory obligation to send and update data on concluded contracts, and changes to such contracts. Moreover, the operation of such a system requires the cooperation of many entities, which may be very difficult to achieve without a coercive law.

\section{Conclusions}

Utility networks disclosed in GESUT do not contain information on the basis of which law a given network is located on the property. The utilities networks are disclosed in GESUT, so it is possible to determine how a given network works. One of the conclusions of the conducted research is the need to develop a map indicating the encumbrances on real estate. When developing maps, basic information can be included about the terms of the contractual use, who owns the network, and who is responsible for maintenance and repair. Thanks to this, everyone will be able to contact the owner of the network 
in related matters. Certainly, such an instrument would apply not only in the acquisition and disposal of real estate, but also in real estate valuation, particularly with regard to whether a utility network is present on the real estate, and how the related rights affect the value of that real estate. Buyers can obtain information about existing rights, so that they can decide whether they want to buy the property. The existence of the utility companies' rights may also limit the possibilities of developing the property in the way the buyer wants. Property appraisers value the property where the utility network is located and need technical information about the devices affecting the land. Stakeholders would have easy access to data, so that they can learn where the utility network is located.

The solution presented is necessary for the proper completion of many procedures related to real estate management. Many entities will be able to use this solution. It will constitute another source of obtaining information about real estate, thanks to which we will obtain data on both the route and the rights of utility companies to areas of real estate. The tests were carried out only for a gas line, and other utility networks may be found in the same area where other utility networks have obtained rights to the land.

Indicating where utility networks are located and the rights associated with them will allow for the planning of crops or investments on that real estate. The presence of utility networks may limit the use of certain cultivation methods or equipment. For this reason, investors and farmers on agricultural land must be aware of the location of facilities on their land. The Sustainable Development Goals will also provide agricultural land with access to utility networks. The entity responsible for the construction of the utility networks supplying electricity, gas, or other utilities must obtain the right to the real estate in order to build these facilities. Thanks to the provision of all necessary utilities, we are improving the functioning of farms, which consequently affects the use of agriculture. The paper presents the restrictions on the use of land in accordance with its designated purpose, taking the example of the designed infrastructure. With information about land classes, the course of infrastructure can be designed in such a way as to avoid the most valuable land. However, for this purpose, cartographic materials must reveal the rights to that land. The thematic layers presented in the article, taking into account their obligatory implementation in geoportals, may in the future form the basis for creating a 3D cadaster. A 3D cadaster has been discussed in the literature [52-58]. The implementation of the 3D cadaster will bring important changes in the concept of property rights in space. "The 3D cadaster will represent complete and comprehensive spatial information not only about land rights, but also about the restrictions and responsibilities imposed on property owners." [59]. Thanks to the layers setting out the property rights, we will not only receive technical, but also legal information about the property of interest. The use of remote sensing methods for aerial images of unmanned aerial vehicles (UAV) helicopters, etc.) will make it possible to verify the marked infrastructure on maps, but only WEBGIS, with disclosed rights, will provide full information about the area. The article shows that the use of remote sensing techniques, GIS, and the disclosure of rights is necessary for the functioning of agriculture, forestry, and spatial planning in rural areas. Particularly in the EU Member States where directives unifying law are established, the introduction of limitations resulting from legal regulations on the location of real estate used as a basis for maps will enable the effective and efficient implementation of the law.

Author Contributions: M.O.: conceptualization, methodology, software, validation, resources, writing-original draft preparation, writing-review and editing, visualization, supervision, project administration, funding acquisition; A.K.: conceptualization, validation, Investigation, resources, writing - original draft preparation, writing-review and editing, project administration, funding acquisition; D.N.: software, data curation, visualization; M.P.: Formal analysis.

Funding: This research was prepared under the statutory research no. 28.610.020-300 and the publication was written as a result of the author's internship at the Head Office of Geodesy and Cartography, co-financed by the European Union under the European Social Fund (Operational Program Knowledge Education Development), carried out under the project Development Program at the University of Warmia and Mazury in Olsztyn (POWR.03.05. 00-00-Z310/17)

Conflicts of Interest: The authors declare no conflicts of interest. 


\section{References and Notes}

1. SDG Zero Hunger. Available online: https://www.un.org/sustainabledevelopment/hunger/ (accessed on 27 September 2019).

2. Alattas, A.; Van Oosterom, P.; Zlatanova, S. Deriving the Technical Model for the Indoor Navigation Prototype Based on the Integration of IndoorGML and LADM Conceptual Model. In Proceedings of the 7th International FIG Workshop on the Land Administration Domain Model, 20-21 October 2018; FIG (International Federation of Surveyors): Copenhagen, Denmark, 2018; pp. 246-266.

3. Alattas, A.; Zlatanova, S.; Van Oosterom, P.; Chatzinikolaou, E.; Lemmen, C.; Li, K.-J. Supporting Indoor Navigation Using Access Rights to Spaces Based on Combined Use of IndoorGML and LADM Models. ISPRS Int. J. Geo-Inf. 2017, 6, 384. [CrossRef]

4. Alattas, A.; van Oosterom, P.; Zlatanova, S.; Diakité, A.; Yan, J. Developing a Database for the LADM-IndoorGML Model. In Proceedings of the 6th International FIG 3D Cadastre Workshop, Delft, The Netherlands, 2-4 October 2018.

5. Elia, E.A.; Zevenbergen, J.A.; Lemmen, C.; van Oosterom, P.J.M. The land administration domain model (LADM) as the reference model for the Cyprus land information system (CLIS). Surv. Rev. 2013, 45, 100-110. [CrossRef]

6. Commission Regulation (EU) No 1253/2013 of 21 October 2013 amending Regulation (EU) No 1089/2010 Implementing Directive 2007/2/EC as Regards Interoperability of Spatial Data Sets 82 V. Cetl et al. and Services (2013). Available online: http://eur-lex.europa.eu/LexUriServ/LexUriServ.do?uri=OJ\%3AL\% 3A2013\%3A331\%3A0001\%3A0267\%3AEN\%3APDF (accessed on 19 November 2019).

7. Directive 2007/2/EC of the European Parliament and of the council of 14 March 2007 Establishing an Infrastructure for Spatial Information in the European Community (INSPIRE). Available online: http: //eur-lex.europa.eu/legal-content/EN/ALL/?uri=CELEX:32007L0002 (accessed on 19 November 2019).

8. INSPIRE Metadata Implementing Rules: Technical guidelines based on EN ISO 19115 and EN ISO 19119. Available online: http://inspire.ec.europa.eu/documents/Metadata/MD_IR_and_ISO_20131029.pdf (accessed on 19 November 2019).

9. Döllner, J.; Jobst, M.; Schmitz, P. (Eds.) Service-Oriented Mapping, Lecture Notes in Geoinformation and Cartography; Springer: Berlin/Heidelberg, Germany, 2018. [CrossRef]

10. Civil Code of 23 April 1964 (Kodeks Cywilny). Article 46. J. Laws 2019. item 1145. Available online: www.isap.sejm.gov.pl (accessed on 19 November 2019). (In Polish).

11. Act on Real Estate Management of 1 August 1997 (ustawa o gospodarce nieruchomosciami). J. Laws 2018. item 2204. Available online: www.isap.sejm.gov.pl (accessed on 19 November 2019). (In Polish).

12. Rudnicki, S. O Pojęciu Nieruchomości w Prawie Cywilnym (On the Concept of Real Estate in Civil Law). In Przeglad Sadowy; Wolters Kluwer: Philadelphia, PA, USA, 1999; Number 9; p. 69.

13. Judgement of Supreme Court of 26 February 2003. II CKN 1306/00, LEX no 83961.

14. Act on Land and Mortgage Registers of 6 July 1982 (o księgach wieczystych i hipotece) Article 21. Laws 2018. item 1916. Available online: www.isap.sejm.gov.pl (accessed on 19 November 2019). (In Polish).

15. Civil Code of 23 April 1964 (Kodeks Cywilny). Article 143. J. Laws 2019. item 1145. Available online: www.isap.sejm.gov.pl (accessed on 19 November 2019). (In Polish).

16. Available online: geoportal.gov.pl (accessed on 27 September 2019).

17. Bojarski, W. Prawo Rzymskie (Roman law); Wydawnictwo Dom Organizatora: Torun, Poland, 1999.

18. Wasilkowski, J. Prawo Własności w PRL (Property Right in the People's Republic of Poland); Panstwowe Wydawnictwo Naukowe: Warsaw, Poland, 1969; p. 133.

19. Geodetic and Cartographic Law of 17 May 1989 (Prawo Geodezyjne i Karograficzne). Article 20. J. Laws 2019. item 725. Available online: www.isap.sejm.gov.pl (accessed on 19 November 2019). (In Polish).

20. Geodetic and Cartographic Law of 17 May 1989 (Prawo Geodezyjne i Karograficzne). Article 24. J. Laws 2019. item 725. Available online: www.isap.sejm.gov.pl (accessed on 19 November 2019). (In Polish).

21. Dawidowicz, A.; Źróbek, R. Ewolucja Potencjału Systeu Katastralnego Nieruchomości w Polsce w Świtle Zaiżęn Międzynarodowej Federacji Geodetów (FIG) (The Evolution of the Potential of the Cadastral System of Real Estate in Poland in the Light of the Assumptions of the International Federation of Surveyors); Studia i Materiały Towarzystwa Naukowego Nieruchomości: Olsztyn, Poland, 2011; Volume 19. 
22. Act on Spatial Planning and Development of 27 March 2003 (o planowaniu i zagospodarowaniu przestrzennym). Article 4. Laws 2018. item 194. Available online: www.isap.sejm.gov.pl (accessed on 19 November 2019). (In Polish).

23. Water Law of 20 July 2017 (prawo wodne). J. Laws 2018. item 2268. Available online: www.isap.sejm.gov.pl (accessed on 19 November 2019). (In Polish).

24. Geological and Mining Law of 9 June 2011 (prawo geologiczne i górnicze). Laws 2019. item 868. Available online: www.isap.sejm.gov.pl (accessed on 19 November 2019). (In Polish).

25. Franco, S.; Tarantino, E.; Figorito, B.; Gualano, S.; D'Onghia, A.M. A tree counting algorithm for precision agriculture tasks. Int. J. Digit. Earth 2013, 6, 94-102. [CrossRef]

26. Tarantino, E.; Figorito, B. Mapping Rural Areas with Widespread Plastic Covered Vineyards Using True Color Aerial Data. Remote Sens. 2012, 4, 1913-1928. [CrossRef]

27. Živatkauskienė, I.; Ogryzek, M.; Kurowska, K.; Nenortaitė, B. Free Public Geodata Services-Theoretical Studies of Approach in Lithuania and Poland. In Proceedings of the 2016 Baltic Geodetic Congress (Geomatics), Gdansk, Poland, 2-4 June 2016.

28. Civil Code 23 April 1964 (Kodeks Cywilny). Article 49. J. Laws 2019. item 1145. Available online: www.isap.sejm.gov.pl (accessed on 19 November 2019). (In Polish).

29. Rykowski, R. Status Prawny Urzadzeń Przesyłowych z Art. 49 k.c.-Uwagi na tle Nowelizacji Kodeksu Cywilnego (The Legal Status of Utility Networks under Art. 49 of the Civil Code-Comments on the Background of the Amendment to the Civil Code); Przegląd Prawa Handlowego: Philadelphia, PA, USA, 2009; Volume 7, p. 47.

30. Stępień-Sporek, A. Status Prawny Urzadzeń Wskazanych w Art. 49 kc (Legal Status of Devices Indicated in Art. 49 of the Civil Code); Monitor Prawniczy: Warszawa, Poland, 2008; Volume 14, p. 736.

31. Doukas, H.; Karakosta, C.; Flamos, A.; Psarras, J. Electric power transmission: An overview of associated burdens. Int. J. Energy Res. 2011, 35, 979-988. [CrossRef]

32. Gniewek, E. (Ed.) System Prawa Prywatnego, Vol. 3, Prawo Rzeczowe (Private Law System, Vol. 3, Law of Property); C.H.Beck: Warsaw, Poland, 2013; p. 4.

33. Judgement of Voivodeship Administrative Court in Szczecinie of 25 October 2006. II SA/SZ 267/06, LEX.

34. Building law of 7 July 1994 (prawo budowlane). Article 32. Laws 2019. item 1186. Available online: www.isap.sejm.gov.pl (accessed on 19 November 2019). (In Polish).

35. Judgment of the Supreme Administrative Court in Warsaw of 11 May 2000. SA/Rz 2826/98, LEX No 657594. Available online: http://orzeczenia.nsa.gov.pl/doc/52CDEEA0AE (accessed on 25 November 2019).

36. Kuźma, G. Prawo Budowlane i Nieruchomości (Construction and Real Estate Law); Okólski, D., Ed.; C.H.Beck: Warsaw, Poland, 2014; p. 11.

37. Judgment of the Supreme Administrative Court of 28 April 2006 r. II OSK 800/05, LEX No 212225. Available online: http://orzeczenia.nsa.gov.pl/doc/A76D180B37 (accessed on 25 November 2019).

38. Technical Instructions G-7. Available online: http://www.gisplay.pl/geodezja/instrukcje/G7.pdf (accessed on 27 September 2019).

39. Šnajberga, O. Valuation of Real Estate with Easement. Procedia Econ. Financ. 2015, 25, 420-427. [CrossRef]

40. Sajnóg, N.; Sobolewska-Mikulska, K. Registration of easements established for transmission companies-Case study of Poland and Canada. Geod. Cartogr. 2018, 67, 131-142. [CrossRef]

41. Depoorter, B.W.F.; Parisi, F. Fragmentation of Property Rights: A Functional Interpretation of the Law of Servitudes; John, M., Ed.; Olin Center for Studies in Law, Economics, and Public Policy Working Papers, Paper 284; 2003; Available online: https://digitalcommons.law.yale.edu/lepp_papers/284 (accessed on 19 November 2019).

42. Hudecova, L.; Kysel, P. Displaying of Easements on the Web Portal within the Context of the Slovak Republic. Geod. List 2019, 73, 67-80.

43. Ogryzek, M.; Ciski, M. Cartographic Methods of Presentation the Average Transaction Prices of the Undeveloped Land. Civil Environ. Eng. Rep. 2018, 28, 85-100. [CrossRef]

44. Right of Way Engineering Manual Oregon. Available online: https://www.oregon.gov/ODOT/ETA/ Documents_Geometronics/ROW-Eng-Manual.pdf (accessed on 27 September 2019).

45. Right of Way Engineering Manual. Available online: https://www.nj.gov/transportation/eng/documents/ ROWE/pdf/ROWEManual.pdf (accessed on 27 September 2019).

46. Right of Way Real Property Asset Management-Prototype Data Architecture. Available online: https: //static.tti.tamu.edu/tti.tamu.edu/documents/0-5788-1.pdf (accessed on 27 September 2019). 
47. Worster, W.T. Maps Serving as Facts or Law in International Law (30 August 2017). Conn. J. Int. Law 2018, 33, 1-26. Available online: http://dx.doi.org/10.2139/ssrn.3073565 (accessed on 27 September 2019).

48. Rakoczy, B. Slużebność Przesyłu w Praktyce (Transmission Easement in Practice); Wydawnictwo LexisNexis: Warsaw, Poland, 2012.

49. Dąbek, J.; Nowakowska, M.; Zamroch, P. Wybrane Zagadnienia Wyceny Nieruchomości a Problematyka Prawna, Ekonomiczna i Przestrzenna Zwiazana z Infrastryktura Techniczna (Selected Real Estate Valuation Issues Versus Legal, Economic and Spatial Issues Related to Technical Infrastructure); Wydawnictwo Replika: Poznań, Poland, 2013.

50. Mentis, D.; Andersson, M.; Howells, M.; Rogner, H.; Siyal, S.; Broad, O.; Korkovelos, A.; Bazilian, M. The Benefits of Geospatial Planning in Energy Access-A case study on Ethiopia. Appl. Geogr. 2016, 72, 1-13. [CrossRef]

51. Meehan, W.; Brook, R.G.; Wyland, J. GIS in Energy and Utilities. Springer. In Handbook of Geographic Information; Kresse, W., Danko, D., Eds.; Springer: Berlin/Heidelberg, Germany, 2011; Available online: https://doi.org/10.1007/978-3-540-72680-7_28 (accessed on 19 November 2019).

52. Stoter, J.; Ploeger, H.; Roes, R.; van der Riet, E.; Biljecki, F.; Ledoux, H. First 3D Cadastral Registration of Multi-Level Ownerships Rights. In Proceedings of the Netherlands 5th International FIG 3D Cadastre Workshop, Athens, Greece, 18-20 October 2016.

53. Kalantari, M.; Rajabifard, A.; Wallace, J.; Williamson, I. Spatially referenced legal property objects. Land Use Policy 2008, 25, 173-181. [CrossRef]

54. Kitsakis, D.; Dimopoulou, E. 3D Cadastres: Legal Approaches and Necessary Reforms. Surv. Rev. 2014, 46, 322-332. [CrossRef]

55. Karabin, M. Registration of the Premises in 2D Cadastral System in Poland. In Proceedings of the FIG Working Week 2011 “Bridging the Gap between Cultures”, Marrakech, Morocco, 18-22 May 2011; 2018. Article No 4818. Available online: www.oicrf.org (accessed on 23 April 2018).

56. Karabin, M. A concept of a model approach to the 3D cadastre in Poland-Technical and legal aspects. In Proceedings of the 4th International FIG 3D Cadastre Workshop, Dubai, UAE, 9-11 November 2014; pp. 281-298.

57. Bydłosz, J. Developing the Polish Cadastral Model towards a 3D Cadastre. In Proceedings of the 5th International FIG 3D Cadastre Workshop, Athens, Greece, 18-20 October 2016.

58. Siejka, M.; Ślusarski, M.; Zygmunt, M. 3D + time Cadastre, possibility of implementation in Poland. Surv. Rev. 2014, 46, 79-89. [CrossRef]

59. Klimach, A.; Bagan-Kurluta, K.; Pietkiewicz, M.; Źróbek, R. Legal Regulations Concerning Access to Public Waters-A Comparative Study. Sustainability 2019, 11, 4578. [CrossRef] 